\title{
Physicochemical, antioxidant and sensory properties of fermented milk beverage with added prebiotic and caja-manga pulp
}

\section{Propriedades físico-químicas, antioxidantes e sensoriais de bebida láctea fermentada adicionada de prebiótico e polpa de cajá-manga}

\section{Fabielle CHEUCZUK'; Luana Aparecida ROCHA²; Marília Pellisson BUSANELLO; Fabiane Picinin CASTRO-CISLAGHI ${ }^{4}$; Alessandra MACHADO-LUNKES ${ }^{5}$}

\begin{abstract}
${ }^{1}$ Discente do Curso de Tecnologia de Alimentos da Universidade Tecnológica Federal do Paraná (UTFPR), Campus Francisco Beltrão. fabielle_cheuczuk@hotmail.com

${ }^{2}$ Discente do Curso de Tecnologia de Alimentos da Universidade Tecnológica Federal do Paraná (UTFPR), Campus Francisco Beltrão. luarocha4@hotmail.com

${ }^{3}$ Discente do Curso de Tecnologia de Alimentos da Universidade Tecnológica Federal do Paraná (UTFPR), Campus Francisco Beltrão. lilabusanello@hotmail.com

${ }^{4}$ Docente do Departamento de Engenharia de Alimentos da Universidade Tecnológica Federal do Paraná, Campus Francisco Beltrão. fabianecastro@utfpr.edu.br

${ }^{5}$ Autor para correspondência. Docente do Departamento de Química e Biologia da Universidade Tecnológica Federal do Paraná (UTFPR). Linha Santa Bárbara, s/n, CEP: 85601-970, Francisco Beltrão/PR-Brasil. *amachado@utfpr.edu.br
\end{abstract}

Recebido em: 21-06-2017; Aceito em: 01-02-2018

\begin{abstract}
The objective of the study was to evaluate the physicochemical, antioxidant and sensory properties of fermented milk beverage with added prebiotic and caja-manga pulp. Three milk beverage formulations were prepared, with $25 \%$ and $30 \%$ caja-manga pulp and a control (pulp-free) formulation. The following were evaluated: physicochemical characteristics ( $\mathrm{pH}$, acidity, proximal composition, color), total phenolics, antioxidants (DPPH, ABTS, FRAP), and sensory properties (preference, acceptance, and purchase intention). Differences were observed between the beverages regarding the physicochemical characteristics, and the composition varied according to the pulp concentration added. The beverages with pulp presented higher phenolic content than control formulation. The formulations with $25 \%$ and $30 \%$ pulp presented antioxidant capacity by the DPPH method with no significant difference between them. However, it was not possible to observe the antioxidant capacity of the pulp-free beverage for this method. No antioxidant capacity was detected by the ABTS and FRAP methods for all beverages studied. The milk beverages presented good sensory acceptance and antioxidant capacity due to the bioactive compounds present in the caja-manga pulp, which contributes to the claim of functionality of this food.
\end{abstract}

Additional keywords: total phenolics; oligofructose; fermented product; Spondias dulcis.

\section{Resumo}

O objetivo do estudo foi avaliar as propriedades físico-químicas, antioxidantes e sensoriais de bebida láctea fermentada adicionada de prebiótico e polpa de cajá-manga. Três formulações de bebida láctea foram preparadas com $25 \%$ e $30 \%$ de polpa de cajá-manga e uma formulação-controle (isenta de polpa). Foram avaliadas as características físico-químicas ( $\mathrm{pH}$, acidez, composição proximal e cor), fenólicos totais, antioxidantes (DPPH, ABTS e FRAP) e sensoriais (preferência, aceitação e intenção de compra). Foram observadas diferenças entre as bebidas quanto às características físico-químicas, sendo que a composição variou de acordo com a concentração de polpa adicionada. As bebidas com polpa apresentaram maior teor de fenólicos que a formulação-controle. As formulações com $25 \%$ e $30 \%$ de polpa apresentaram capacidade antioxidante pelo método DPPH sem diferença significativa entre si. Entretanto, não foi possível observar capacidade antioxidante da bebida sem polpa para este método. Não foi detectada capacidade antioxidante pelos métodos ABTS e FRAP para todas as bebidas estudadas. As bebidas lácteas apresentaram boa aceitação sensorial e capacidade antioxidante decorrente dos compostos bioativos presentes na polpa de cajá-manga, o que contribui para a alegação de funcionalidade deste alimento.

Palavras-chave adicionais: fenólicos totais; oligofrutose; produto fermentado; Spondias dulcis.

\section{Introduction}

Brazil occupies the sixth place in the world production of milk, with a production volume in 2016 of about 27 million tons. Regarding milk products, the high production of cheese ranks the country as the fourth largest producer (766 thousand tons) (USDA, 2016). Whey is the byproduct of cheese production, of high nutritional value (rich in calcium and phosphorus), whose proteins 
have excellent functional properties. However, whey has a high organic matter content, and great polluting potential when unduly discarded ( $\mathrm{Ha}$ \& Zemel, 2003; Siqueira et al., 2013). In this way, the use of whey has a great environmental appeal and considerable economic importance since it is involved in the preparation of desserts, beverages, soups, meat products, dairy products, and bakery products (Alves et al., 2014).

With the increasing demand for healthier products, the food industry has been investing more and more in the manufacture of milk beverages, using a mixture of whey and other ingredients in their formulation (Castro et al., 2009). Among these ingredients, oligofructose stands out, one of the main prebiotics available on the market, capable of promoting health benefits due to the modulation of the intestinal microbiota (FAO/AGNS, 2007). Oligofructose consumption inhibits the growth of pathogens in the gut, increases calcium absorption from the diet, and alleviates the symptoms of constipation (Saad et al., 2013). In addition to oligofructose, in the formulation of some milk beverages, fruit pulps are added, which provide pleasant sensory properties (Siqueira et al., 2013). These fruits contain in their composition bioactive compounds that help in the prevention of certain diseases (Yahia, 2009), and if properly processed, can maintain the contents of bioactive compounds (Fabbri \& Crosby, 2016). These phytochemicals are products of secondary metabolism, whose large number of diversified structures are divided into several classes according to their carbon skeleton (Martinez-Valverde et al., 2000). Among them stand out the phenolic compounds, known to exhibit antioxidant activity, whose action is related to the number and position of hydroxyls present in the molecule (Rice-Evans, 1996).

Caja-manga (Spondias dulcis), an exotic fruit originating from Polynesia (Youmbi et al., 2010), is little known to the general public, and is cultivated in the North and Northeast of Brazil, being also known as cajarana and taperebá-dosertão (Ribeiro, 2010). This fruit, which on the European continent is known as ambarella or golden apple, has a pleasant aroma and taste, and a considerable content of vitamins, minerals and phenolic compounds (Graham et al., 2004). Due to its good sensory and nutritional properties, caja-manga has aroused interest in the development of different products (Damiani et al., 2011; Lago-Vanzela et al., 2011).

The objective of this work was to evaluate the antioxidant properties of caja-manga pulp and the effects of its addition on the physicochemical, antioxidant and sensory characteristics of fermented milk beverages.

\section{Material and methods}

\section{Production of fermented milk beverage}

The mature fruits of caja-manga (Spondias dulcis) (75\% of the skin with yellow color), according to classification for fruits that ripen from green to yellow (De Oliveira et al., 2002), were purchased in the city of Ribeirão Preto-SP, Brazil. The fruits were washed and soaked in sodium hypochloride $\left(50 \mathrm{mg} \mathrm{L}^{-1}\right)$ for 15 minutes. Then, the whole fruits were submerged in water at $80^{\circ} \mathrm{C} / 30$ minutes. The fruits were peeled, the peel was scraped, and the obtained mass was sieved for retention of the lump and fibers. The obtained pulp was homogenized and the total soluble solids of the pulp were determined using a refractometer (BioBrix, Curitiba, Brazil). Sucrose was added up to the concentration of $40^{\circ} \mathrm{Brix}$, and then the pulp was pasteurized at $90{ }^{\circ} \mathrm{C} / 2$ minutes. The pulp was stored in plastic containers and kept under freezing $\left(-18^{\circ} \mathrm{C}\right)$ until use.

In the elaboration of the fermented milk beverage, homogenized pasteurized milk was used, with fat content standardized at $3 \%$, and whey from Minas Frescal cheese production. The milk/whey mixture (70:30) with added powdered milk $(1 \% \mathrm{w} / \mathrm{v})$, sucrose $(8 \% \mathrm{w} / \mathrm{v})$, oligofructose (10\% w/v; Beneo®, Clariant-Orafti) and thickener $(0.5 \% \mathrm{w} / \mathrm{v}$; modified starch and gelatin - TECGEM AA 073 BF, Gemacom Tech) was pasteurized at $65^{\circ} \mathrm{C} / 30$ minutes and cooled to $37^{\circ} \mathrm{C}$, when the lactic culture consisting of Lactobacillus acidophillus La-5, Bifidobacterium Bb-12, and Streptococcus thermophilus (BioRich®, Chr. Hansen) was added. BioRich® culture was chosen for its rapid acidification and because it contains probiotic microorganisms, being added according to the manufacturer's recommendations described on the product label (1 packet - $400 \mathrm{mg}$ for 1 liter of beverage). Fermentation was carried out at $37{ }^{\circ} \mathrm{C}$ for an average period of four hours. The $\mathrm{pH}$ was measured during fermentation until $\mathrm{pH}$ 4.6. After fermentation, the milk beverages were cooled, gently stirred, and the caja-manga pulp was added. Pulp concentrations were determined through preliminary tests, where formulations containing 25 and 30\% caja-manga (beverages B25 and B30) showed acceptable fruit flavor characteristics. In the physicochemical analyses, for comparison purposes, a control beverage (BC) without the addition of fruit pulp was elaborated. The milk beverage manufacture was repeated three times for each formulation.

\section{Physicochemical analyses}

The physicochemical analyses were performed in triplicate regarding the caja-manga pulp and milk beverages in up to 7 days from the preparation date. The $\mathrm{pH}$, acidity, moisture, total 
solids, lipids, proteins, ashes, and total carbohydrates (by difference) were determined (AOAC, 2005).

For color analysis, the Minolta Chroma Meter CR-400 colorimeter (Konica Minotta, Japan) was used, and a standard ceramic white was used as a blank. The analyzed parameters were $L^{*}$ (luminosity), $a^{*}$ (red - green component), and $b^{*}$ (yellow - blue component). Five measurements were taken for each sample.

\section{Determination of phenolic compounds and antioxidant capacity}

The extraction of phenolic compounds was carried out the day after the production of the caja-manga pulp and milk beverage. The resulting extract was kept under refrigeration $\left(5^{\circ} \mathrm{C}\right)$ until analysis to determine the total phenolic content and antioxidant capacity. These analyses occurred within 21 days after the production and were performed in triplicate.

For the extraction of phenolic compounds and determination of the antioxidant capacity of the caja-manga pulp and milk beverages (BC, $\mathrm{B} 25$, and B30), $50 \mathrm{~g}$ of the sample were extracted with methanolic solution, and the resulting mixture was filtered and diluted (Larrauri et al., 1997; Canuto et al., 2010). All solutions were centrifuged at $6000 \mathrm{rpm}$, with the supernatant being separated and conditioned in a freezer until spectrophotometric analysis.

The content of total phenolic compounds was determined according to the Folin-Ciocalteau method by interpolating the absorbance of the samples against a calibration curve constructed with gallic acid standards $\left(0.010\right.$ to $\left.0.045 \mathrm{mmol} \mathrm{L}^{-1}\right)$. Absorbance was measured on a DR 5000 spectrophotometer (Thermo Scientific, USA) at $765 \mathrm{~nm}$, and the results expressed as milligram gallic acid equivalent (GAE) per $100 \mathrm{~g}$ sample (Kim et al., 2003).

To determine the antioxidant capacity of the caja-manga pulp and milk beverages, $10 \mu \mathrm{L}$ of each sample was added to $4 \mathrm{~mL}$ of the solution of the cation radical of 2,2'-azino-bis (3-ethylbenzothiazoline-6-sulfonic acid) (ABTS•+) diluted. After six minutes of reaction, spectrophotometer reading was performed at $734 \mathrm{~nm}$, and the responses were expressed as $\mu \mathrm{M}$ Trolox $100 \mathrm{~g}^{-1}$ sample by comparing the absorbances of the samples with a calibration curve plotted for Trolox methanolic solutions (1.0 to $8.0 \mathrm{mmol} \mathrm{L}^{-1}$ ) (Sánchez-González et al., 2005). The antioxidant capacity of the samples to reduce iron was evaluated using the FRAP reagent. The test was performed with $4.4 \mathrm{~mL}$ FRAP [mixture containing 2,4,6-tri (2-pyridyl)-s-triazine (TPTZ), $\mathrm{FeCl}_{3}$, and acetate buffer], with $441 \mu \mathrm{L}$ water and a $147 \mu \mathrm{L}$ aliquot of the Trolox standard solution or the sample. The mixture was homogenized and maintained in a water bath at $37^{\circ} \mathrm{C} / 30$ minutes. Standard Trolox solutions at different concentrations (100 to $1000 \mathrm{mmol} \mathrm{L}^{-1}$ ) were used for calibration, and the results were expressed as $\mu \mathrm{M}$ trolox $100 \mathrm{~g}^{-1}$ sample (Rufino et al., 2006).

The capacity to scavenge the radical 2,2-diphenyl-1-picrylhydrazyl (DPPH•) was evaluated in a method described by Rufino et al. (2007). After appropriate dilutions, $0.1 \mathrm{~mL}$ of each diluted sample was transferred to a tube containing 3.9 $\mathrm{mL}$ of the DPPH solution. The spectrophotometer readings of the samples, at $515 \mathrm{~nm}$, were monitored every minute, where absorbance reduction was observed until its stabilization. The result was expressed as efficient concentration $\left(E_{50}\right)$, i.e., the amount of antioxidant needed to decrease the initial concentration of DPPH by $50 \%$.

\section{Microbiological and sensory analysis}

Prior to the sensory analysis, coliforms were determined at $35^{\circ} \mathrm{C}$ and $45^{\circ} \mathrm{C}$ (Most Probable Number - MPN) in order to guarantee the microbiological safety of the milk beverages (Brasil, 2003). The sensory analysis of milk beverages with added caja-manga pulp was performed by 95 untrained judges (Dutcosky, 2007). The following tests were performed: paired preference test; overall acceptance test, through a nine-point hedonic scale (ranging from 1, "dislike extremely", to 9, "like extremely"); and purchase intention test, with a 5-point scale (ranging from 1, "definitely would not buy", to 5, "definitely would buy"). Samples were codified and served to the judges, simultaneously, in plastic cups $(50 \mathrm{~mL})$, at $4 \pm 1{ }^{\circ} \mathrm{C}$.

\section{Statistical analysis}

The results were submitted to analysis of variance, and significant differences among the samples were evaluated using the Tukey test at $5 \%$ significance level, performed using Statistica software version 7.0 (Statsoft Inc., Tulsa, OK, USA). To evaluate the data regarding acceptance, purchase intention, and antioxidant capacity by the DPPH method, Student's t-test was applied. Data of the sensory preference test were analyzed using the significance table for two-tailed paired test at $5 \%$ probability level (Dutcosky, 2007). Data were expressed as mean \pm standard deviation.

\section{Results and discussion}

\section{Physicochemical analyses}

Table 1 presents the results of the physicochemical analyses performed for cajamanga pulp and milk beverages (BC, B25, and $\mathrm{B} 30)$. The $\mathrm{pH}$ of beverages B25 (4.17) and B30 (4.11) was lower than that of the control beverage 
$\mathrm{BC}$ (4.61), and this may be related to the use of fruit pulp, which contributes to keeping the $\mathrm{pH}$ low. In fact, the caja-manga pulp presented acidic $\mathrm{pH}$ values similar to previous studies of caja-manga pulp (2.78 to 2.81) and acid fruits grown in Brazil, such as carambola (1.94 to 3.37) (Aché \& Ribeiro, 1950; Lima et al., 2012). The acidity found in milk beverages ranged from 0.59 to $0.71 \mathrm{~g}$ lactic acid $100 \mathrm{~g}^{-1}$, results close to those found by Cunha et al. (2008), who described values of 0.70 to $0.72 \mathrm{~g}$ lactic acid $100 \mathrm{~g}^{-1}$. The legislation does not establish acid values for fermented milk bever- ages, however, the values obtained are within the usual values of acidity $(0.6$ to $2.0 \mathrm{~g}$ lactic acid $100 \mathrm{~g}^{-1}$ ) for fermented milks (Brasil, 2007).

The greater the addition of caja-manga pulp, the greater the amount of total solids found in beverages $\mathrm{B} 25$ and $\mathrm{B} 30$, and consequently the lower the moisture. The pulp presented lower moisture content when compared to other literature reports for caja-manga pulp, whose

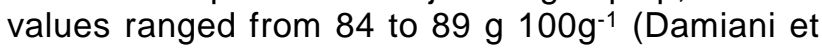
al., 2011; Lima et al., 2012).

Table 1 - Physicochemical characterization of caja-manga pulp and fermented milk beverages.

\begin{tabular}{|c|c|c|c|c|}
\hline Parameters & $\begin{array}{l}\text { Caja-manga } \\
\text { pulp }\end{array}$ & $B C^{(1)}$ & B25 & B30 \\
\hline $\mathrm{pH}$ & $2.82 \pm 0.01$ & $4.61 \pm 0.01 \mathrm{a}$ & $4.17 \pm 0.01 b$ & $4.11 \pm 0.01 c$ \\
\hline Acidity $^{2}$ & $1.32 \pm 0.04$ & $0.59 \pm 0.03 b$ & $0.71 \pm 0.02 a$ & $0.71 \pm 0.01 \mathrm{a}$ \\
\hline Moisture (g $\left.100 \mathrm{~g}^{-1}\right)$ & $61.26 \pm 0.27$ & $74.81 \pm 0.06 a$ & $71.95 \pm 0.07 b$ & $71.07 \pm 0.02 c$ \\
\hline Soluble solids (g $100 \mathrm{~g}^{-1}$ ) & $38.74 \pm 0.27$ & $25.19 \pm 0.06 c$ & $28.06 \pm 0.07 b$ & $28.94 \pm 0.02 a$ \\
\hline Protein $\left(\mathrm{g} 100 \mathrm{~g}^{-1}\right)$ & $1.43 \pm 0.31$ & $2.62 \pm 0.03 a$ & $2.31 \pm 0.02 b$ & $2.13 \pm 0.02 c$ \\
\hline Lipid $\left(\mathrm{g} 100 \mathrm{~g}^{-1}\right)$ & $0.03 \pm 0.01$ & $2.15 \pm 0.01 a$ & $2.01 \pm 0.02 b$ & $2.05 \pm 0.03 b$ \\
\hline Ash $\left(\mathrm{g} 100 \mathrm{~g}^{-1}\right)$ & $0.46 \pm 0.01$ & $0.69 \pm 0.00 a$ & $0.62 \pm 0.00 b$ & $0.62 \pm 0.00 \mathrm{~b}$ \\
\hline Carbohydrates $\left(\mathrm{g} 100 \mathrm{~g}^{-1}\right)$ & $37.02 \pm 0.29$ & $19.79 \pm 0.13 c$ & $23.05 \pm 0.19 b$ & $24.08 \pm 08 a$ \\
\hline \multicolumn{5}{|l|}{ Color parameters ${ }^{3}$} \\
\hline$L^{*}$ & $38.09 \pm 1.10$ & $82.83 \pm 0.04 a$ & $76.80 \pm 0.07 b$ & $76.20 \pm 0.32 c$ \\
\hline$a^{*}$ & $2.27 \pm 0.19$ & $4.00 \pm 0.01 c$ & $4.70 \pm 0.20 a$ & $4.58 \pm 0.05 b$ \\
\hline$b^{*}$ & $18.02 \pm 0.36$ & $8.70 \pm 0.02 c$ & $16.76 \pm 0.06 b$ & $18.39 \pm 0.11 \mathrm{a}$ \\
\hline
\end{tabular}

(1) BC - Beverage control; B25 - beverage with 25\% of pulp; B30 - beverage with $30 \%$ of pulp; 2 citric acid $100 \mathrm{~g}^{-1}$ for the preparation of pulp and lactic acid $100 \mathrm{~g}^{-1}$ for the milk beverages; 3 Results expressed as mean \pm standard deviation of three repetitions in triplicate, except for color parameters (five replicates). Different letters in the same line indicate a significant difference by the Tukey test $(p<0.05)$.

Even though the amount of proteins was higher than that described in the literature $(0.78$ to

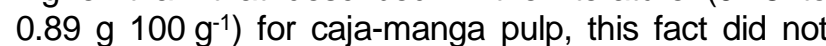
increase the concentration of protein in beverages B25 and B30. Beverage B30, which presented the lowest protein content, is in accordance with the current legislation that determines a minimum protein content

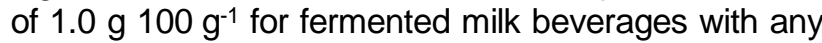
addition (Brasil, 2005; Damiani et al., 2011; Lima et al., 2012).

Regarding lipids, it was observed that the sample BC presented a higher percentage when compared to beverages B25 and B30. However, there was no significant difference between the beverages added with pulp ( $p>0.05)$. Similar to that observed for protein contents, the amount of lipids in the pulp, which was lower than those reported in the literature (0.59 to $0.61 \mathrm{~g} 100 \mathrm{~g}^{-1}$ ), did not increase the lipid content of beverages with added caja-manga pulp (Damiani et al., 2011; Lima et al., 2012).

The ash content of $\mathrm{BC}$ was higher than those beverages B25 and B30 ( $\mathrm{p}<0.05)$, according to Table 1. Carbohydrate content ranged from 19.79 to $24.08 \mathrm{~g}$ $100 \mathrm{~g}^{-1}$ for lactic beverages (Table 1) (including added oligofructose). BC presented lower content than beverages B25 and B30 $(p<0.05)$. This is due to the presence of sucrose and other sugars from the fruit itself in the pulp preparation, which increased the carbohydrate contents of beverages added with the caja-manga pulp.

In relation to the color parameters of the milk beverages, the increase in the amount of caja-manga pulp decreased the value of $L^{*}$, and this decrease of luminosity may have been influenced by the color of the caja-manga pulp, since the color of the ingredients used in the formulation influences directly on the color of the product (Dello Staffolo et al., 2004; Aryana \& McGrew, 2007). Beverages B25 and B30 presented higher values $(p<0.05)$ than $B C$ for the coordinates $a^{*}$ and $b^{*}$ as a function of the increase in the addition of the pulp, i.e., the addition of the pulp contributed to the increase of the yellow coloration.

\section{Determination of phenolic compounds and antioxidant capacity}

The result obtained in the determination of the total phenolic compounds (TP) of the caja-manga preparation was $47.86 \mathrm{mg} \mathrm{GAE} 100 \mathrm{~g}^{-1}$ sample (Table 2). 
Table 2 - Total phenolic content and antioxidant capacity by ABTS, DPPH and FRAP assay of caja-manga pulp and fermented milk beverages.

\begin{tabular}{|c|c|c|c|c|}
\hline Assay $^{1}$ & Caja-manga pulp & $\mathrm{BC}(2)$ & B25 & B30 \\
\hline TP $\left(m g \text { GAE } 100 \mathrm{~g}^{-1}\right)^{(3)}$ & $47.86 \pm 1.44$ & $2252.94 \pm 120.23 b$ & $3174.21 \pm 49.73 a$ & $3262.52 \pm 75.15 a$ \\
\hline ABTS $\left(\mu \mathrm{M}\right.$ trolox $\left.100 \mathrm{~g}^{-1}\right)$ & $220.99 \pm 67.32$ & ND (4) & ND & ND \\
\hline $\operatorname{FRAP}\left(\mu \mathrm{M}\right.$ trolox $\left.100 \mathrm{~g}^{-1}\right)$ & $108.10 \pm 5.35$ & ND & ND & ND \\
\hline $\mathrm{DPPH}\left(\mathrm{EC}_{50} \mu \mathrm{g} \mathrm{mL}^{-1}\right)$ & $15.62 \pm 2.13$ & ND & $2434.95 \pm 1.41 \mathrm{a}$ & $2107.33 \pm 114.20 a$ \\
\hline
\end{tabular}

(1) Results expressed as mean \pm standard deviation of three repetitions in triplicate; (2) BC - control beverage; B25 - beverage with $25 \%$ of pulp; B30 - beverage with $30 \%$ of pulp; (3) GAE - gallic acid equivalent; (4) ND - not detected; Different letters in the same line indicate a significant difference $(p<0.05)$ (by Tukey's test; for DPPH by t-test).

In the study by Islam et al. (2013), when determining the content of phenolic compounds in caja-manga, the authors obtained the following values for the methanolic and chloroform extract: 659.74 and $214.59 \mathrm{mg} \mathrm{GAE} \mathrm{g}^{-1}$ dried fruit, respectively. The lower TP of this work may be related to the fact that a pulp was used instead of a dried fruit such as in Islam et al. (2013). In a study by Melo et al. (2010) and Vieira et al. (2011), fruit pulp analysis showed that umbu (Spondias tuberosa) and caja (Spondias mombin L) presented phenolic compound contents of $32.70 \mathrm{mg}$ catechin

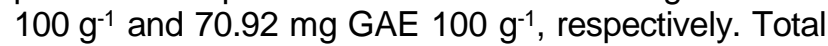
phenolics was reported for yellow fruits such as physalis (Rockenbach et al., 2008) and mango (Vasco et al., 2008) to be in the order of 57.9 and $60.0 \mathrm{mg}$ GAE $100 \mathrm{~g}^{-1}$, respectively. Thus, the results found for the caja-manga pulp (Table 2) are close to that of fruits of the genus Spondias and other yellow fruits (physalis and mango), whose phenolic compound extraction used both a methanolic solution and a method of determining TP similar to this work.

Beverages B25 and B30 did not show any difference in the content of phenolic compounds (Table 2). The milk beverages with caja-manga pulp had a higher content of phenolic compounds than the control beverage $(p<0.05)$ due to the aggregation of phenolic compounds of the caja-manga pulp. In addition, BC has phenolic compounds, which may be related to the presence of phenolic compounds in milk (thiophenol, phenol, o-cresol, $p$-cresol, m-cresol, 2-ethylphenol, thymol, and carvacrol), previously described in studies conducted by Conell \& Fox (2001).

To evaluate the antioxidant capacity of fruits and byproducts or associated products, the methods differ according to the experimental conditions and the way of quantifying the antioxidant capacity, thus, a set of different methods is used for evaluation (Wojdylo et al., 2008). The antioxidant capacity of the caja-manga pulp was evaluated using different methods: ability to react with $A B T S \bullet+$ radical, reducing power measured by the FRAP method, and scavenging of DPPH $\bullet$ free radicals. The caja-manga pulp was able to scavenge ABTS $\bullet+$ and DPPH $\bullet$ free radicals, as reported by Costa (2010) for caja-manga extract. Costa (2010) reported that the caja-manga extract concentration that inhibited or scavenged $50 \%$ of the reactive species $\left(\mathrm{IC}_{50}\right)$ by ABTS and DPPH methods was $17.92 \%$ and $42.53 \%$, respectively. There is no way to make a direct comparison with the work of Costa (2010), since there is difference in the unit of expression of the results, as well as in the technique and solvents used. In fact, in the preparation of samples, Costa (2010) used phosphate buffer $(\mathrm{pH}=7)$ to extract compounds with antioxidant action, and it is known that the solvent has an effect on the antioxidant capacity of food (PérezJiménez \& Saura-Calixto, 2006). Similarly, Vieira (2010) described the same difficulties in comparing their results with those in the literature in studies that determined the antioxidant capacity of apple. Regarding the antioxidant analysis by FRAP method, this is the first work that presents results for this analysis. As there are no other works, it is not possible to compare, but based on a yellow fruit such as physalis, Lopez et al. (2013), using the FRAP method, described antioxidant capacity of $99.70 \mu \mathrm{M}$ trolox $100 \mathrm{~g}^{-1}$ fruit.

For the pulp-free milk beverage (CB), it was not possible to observe the scavenging capacity of $\mathrm{DPPH} \bullet$ free radicals, while the milk beverages elaborated with different concentrations of caja-manga preparation did not differ from each other $(p>0.05)$ (Table 2). The antioxidant capacity of the beverage depends on the existence of a sufficient phenolic content (Almeida et al., 2011). It is believed that the incorporation of the pulp contributed to this phenolic content and the quality thereof (constituents and structural conformation of the phenolic compound), giving beverages B25 and B30 the ability to express antioxidant capacity (Prior et al., 2005; Almeida et al., 2011). In fact, the DPPH method may present negative results for the analysis of products whose antioxidants are of high molar mass since these structures may present steric hindrance, thus not reacting with DPPH• (Pérez-Jiménez et al., 2008).

The milk beverages were also analyzed by ABTS method, but it was not possible to observe the capture of the radical. The absence of antioxidant capacity may be related to the $\mathrm{pH}$ of the test, of 4.6 ,

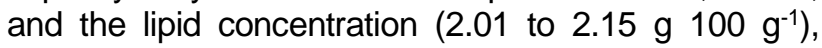
since Chen et al. (2003) reported that the antioxidant response in ABTS method occurs at pH 5 and with low

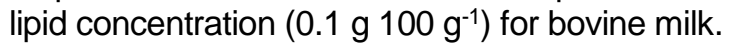

For the FRAP assay, the results of milk beverages (70:30, milk:whey) were not positive, similar to the work of Chen et al. (2003), who observed antioxidant capacity only for the whey from bovine milk. 
However, Najgebauer-Lejko et al. (2011) described antioxidant capacity by FRAP method for yogurt with and without green tea extract supplementation. Considering these reports, the different constituents and interactions between them may explain the various responses of antioxidant capacity (Pérez-Jiménez \& Saura-Calixto, 2006). Indeed, the differences in relation to the other studies may be related to the interactions between the constituents of the food matrix and/or the low amount of whey used in the formulation, in addition to the different basis of each method.

\section{Microbiological and sensory analyses}

In order to guarantee safety in the sensory analyses, coliforms were counted at 35 and $45^{\circ} \mathrm{C}$, and beverages B25 and B30 were not contaminated by coliforms $\left(<0.3 \mathrm{MPN} \mathrm{mL}^{-1}\right)$, in accordance with the standard required by legislation (Brasil, 2001). In the sensory analyses, the beverages with added pulp (B25 and B30) did not present significant difference in the preference test $(p>0.05)$. Regarding acceptance, values of 7.94 (B25) and 7.80 (B30) were obtained. Both milk beverages were accepted. Acceptability indexes were $88.22 \%$ and $86.67 \%$, respectively, with no differences between them $(p>0.05)$. According to Dutcosky (2007), for a product to be considered sensorially accepted, it must obtain an acceptability rate of at least $70 \%$. Thus, the milk beverages with added caja-manga pulp obtained good acceptance by the judges, which shows the interest for different flavors. Regarding the purchase intention, the samples also did not present a significant difference $(p>0.05)$, with mean values of 4.12 (B25) and 4.02 (B30), which correspond to "probably would buy". For beverage B25, $78.57 \%$ of the judges answered that they would "probably" or "definitely" buy the product (sum of the judges who answered notes 4 and 5), while for beverage B30, same response was given by $70.41 \%$ of the judges. These results indicate that if the beverages were offered for sale, they would probably have a satisfactory demand.

\section{Conclusions}

The addition of caja-manga pulp significantly affects the antioxidant capacity of the milk beverage by $\mathrm{DPPH}$ method. It was not possible to detect antioxidant capacity by FRAP and ABTS methods.

Fermented milk beverages with added cajamanga pulp showed good sensory acceptability and purchase intention by the judges. The addition of cajamanga pulp modified the physicochemical characteristics of the milk beverages, and the use of prebiotic contributed to the functional properties of the product. The elaboration of prebiotic fermented milk beverages flavored with caja-manga is an alternative for the use of this fruit in a new product and adding the properties of whey and oligofructose.

\section{Acknowledgements}

To the National Council for Scientific and Technological Development (CNPq), for granting financial support to the research (479636/2011-7).

\section{References}

Aché L, Ribeiro IF (1950) O pH de frutas nacionais. Revista da Faculdade de Medicina Veterinária 4(2):267-269.

Almeida MMB, Sousa PHM, Arriaga AMC, Prado GM, Magalhães CEC, Maia GA, Lemos TLG (2011) Bioactive compounds and antioxidant activity of fresh exotic fruits from northeastern Brazil 44(7):2155-2159.

Alves MP, Moreira RO, Rodrigues Junior, PH, Martins, MCF, Perrone ÍT, Carvalho AF (2014) Soro de leite: tecnologia para o processamento de coprodutos. Revista do Instituto de Laticínios Cândido Tostes 69(3):212-226.

AOAC. Association of Official Analytical Chemists (2005) Official methods of the AOAC International. 18th ed. Gaithersburg.

Aryana KJ, Mcgrew P (2007) Quality attributes of yogurt with Lactobacillus casei and various prebiotics. LWT - Food Science and Technology 40(10):18081814.

Brasil (2001) Ministério da Saúde. Agência Nacional de Vigilância Sanitária. Regulamento sobre padrões microbiológicos para alimentos. Resolução RDC $n^{\circ} 12$, de 02 de janeiro de 2001. Diário Oficial da Republica Federativa do Brasil, n.7, seção I, p.45-53.

Brasil (2003) Ministério da Agricultura, Pecuária e Abastecimento. Instrução Normativa no 62 , de 26 de agosto de 2003. Diário Oficial da República Federativa do Brasil. Brasília, DF.

Brasil (2005) Ministério da Agricultura, Pecuária e Abastecimento. Regulamento Técnico de Identidade e Qualidade de Bebida Láctea. Instrução Normativa no 16 , de 23 de agosto de 2005. Diário Oficial da Republica Federativa do Brasil. Seção I, 23 de agosto, 2005

Brasil (2007) Ministério da Agricultura, Pecuária e Abastecimento. Regulamento Técnico de Identidade e Qualidade de Leites Fermentados. Instrução Normativa $n^{\circ} 46$, de 23 de outubro de 2007. Diário Oficial da União, Brasília, DF, 24 outubro 2007, sec. 1, p. 5.

Canuto GAB, Xavier AAO, Neves LC, Benassi MT (2010) Caraterização físico-química de polpas de frutos da Amazônia e sua correlação com a atividade anti-radical livre. Revista Brasileira de Fruticultura 32(4):1196-1205. 
Castro FP, Cunha TM, Ogliari PJ, Teófilo RF, Ferreira MMC, Prudêncio ES (2009) Influence of different content of cheese whey and oligofructose on the properties of fermented lactic beverages: study using response surface methodology. LWT - Food Science and Technology 42(5):993-97.

Chen J, Lindmark-Mansson H, Gorton L, Akesson B (2003) Antioxidant capacity of bovine milk as assayed by spectrophotometric and amperometric methods. International Dairy Journal 13(12):927-935.

Conell JE, Fox PF (2001) Significance and applications of phenolic compounds in the production and quality of milk and dairy products: a review. International Dairy Journal 11(3):103-120.

Costa, MP (2010) Estudo da atividade antioxidante de frutas tropicais exóticas sobre espécies reativas de oxigênio de importância biológica em ensaios modelos. 130 f. Dissertação (Mestre em Biociências e Biotecnologia Aplicada a Farmácia. Universidade Estadual Paulista Araraquara.

Cunha TM, Castro FP, Barreto PLM, Benedet HD, Prudencio ES (2008) Avaliação físico-química, microbiológica e reológica de bebida láctea e leite fermentado adicionados de probióticos. Semina: Ciências Agrárias 29(1):103-116.

Damiani C, Silva FA, Amorim CCM, Silva STP, Bastos IM, Asquieri ER, Vera R (2011) Néctar misto de cajámanga com hortelã: caracterização química, microbiológica e sensorial. Revista Brasileira de Produtos Agroindustriais 13(3):299-307.

De Oliveira MAB, Vianni R, Souza G, Araújo TMR (2002) Caracterização do estágio de maturação do papaia 'Golden' em função da cor. Revista Brasileira de Fruticultura 24(2):559-561.

Dello Staffolo M, Bertola N, Martino M, Bevilacqua A (2004) Influence of dietary fiber addition on sensory and rheological properties of yogurt. International Dairy Journal 14(3):263-268.

Dutcosky SD (2007) Análise sensorial de Alimentos. 2. Ed. Curitiba: Champagnat.

Fabbri ADT, Crosby GA (2016) A review of the impact of preparation and cooking on the nutritional quality of vegetables and legumes. International Journal of Gastronomy and Food Science 3:2-11.

FAO/AGNS. Food and Agriculture Organization of the United Nations. Food quality and standards service (2007) Technical meeting report on prebiotics. Disponível em: <https://www.aattaa.eu/index/en/company/download/ 1262610500.html> (Acessado em 30 ago 2016).
Graham OS, Wickham LD, Mohammed M. (2004) Growth, development and quality attributes of miniature Golden apple fruit (Spondias cytherea Sonn.). Part II: physicochemical and organoleptic attributes associated with ripening. Food, Agriculture and Environment 2(1):101-106.

Ha E, Zemel MB (2003) Functional properties of whey, whey components, and essential amino acids: mechanisms underlying health benefits for active people. Journal of Nutritional Biochemistry 14(5):251258.

Islam SMDA, Ahmed KHT, Manik MK, Wahid MDA, Kamal CSI (2013) A comparative study of the antioxidante, cytotoxic and thrombolytic potential of the fruits and leaves of Spondias dulcis. Asian Pacific Journal of Tropical Biomedicine 3(9):682-691.

Kim D, Jeong S, Lee CY (2003) Antioxidant capacity of phenolic phytochemicals from various cultivars of plums. Food Chemistry 81(3):321-326.

Lago-Vanzela ES, Ramin P, Umsza-Guez MA, Santos GV, Gomes E, Silva R (2011) Chemical and sensory characteristics of pulp and peel 'cajá-manga' (Spondias cytherea Sonn.) jelly. Ciência e Tecnologia de Alimentos 31(2):398-405.

Larrauri JA, Rupérez P, Saura-Calixto F (1997) Effect of drying temperature on the stabilitity of polyphenols and antioxidant activity of red grape pomace peels. Journal of Agricultural and Food Chemistry 45(4):13901393.

Lima FSL, Lima EQ, Oliveira E, Neto JTF (2012) Caracterização físico-quimica e bromatológica da polpa de Spondias sp (Cajarana). Revista de Biologia e Farmácia 7(1):44-56.

Lopez J, Vega-Gálvez A, Torres MJ, Lemus-Mondaca R, Quispe-Fuentes I, Di Scala K (2013) Effect of dehydration temperature on physico-chemical properties and antioxidant capacity of goldenberry (Physalis peruviana L.). Chilean Journal of Agricultural Research 73(3):293-300.

Martinez-Valverde I, Periago MJ, Ros G (2000) Nutritional importance of phenolic compounds in the diet. Archivos Latinoamericanos de Nutrición. 50(1):518.

Melo EA, Andrade RAMS (2010) Compostos bioativos e potencial antioxidante de frutos do umbuzeiro. Alimentos e Nutrição 21(3):453-457.

Najgebauer-Lejko D, Sady M, Grega T, Walczycka M. (2011) The impact of tea supplementation on microflora, $\mathrm{pH}$ and antioxidant capacity of yoghurt. International Dairy Journal 21(8):568-574. 
Pérez-Jiménez J, Arranz S, Tabenero M, Díaz-Rubio ME, Serrano J, Goñi I, Saura-Calixto F (2008) Updated methodology to determine antioxidant capacity in plant foods, oils and beverages: Extraction, measurement and expression of results. Food Research International 41(3):274-285.

Pérez-Jiménez J, Saura-Calixto F. (2006) Effect of solvent and certain food constituents on different antioxidant capacity assays. Food Research International 39(7):791-800.

Prior RL, Wu X, Schaich K (2005) Standardized methods for the determination of antioxidant capacity and phenolics in foods and dietary supplements. Journal of Agricultural and Food Chemistry 53(10):4290-4302.

Ribeiro GD (2010) Algumas espécies de plantas reunidas por famílias e suas propriedades. Porto Velho: Embrapa Rondônia; 179 p.

Rice-Evans CA, Miller NJ, Paganga G (1996) Structure-antioxidant activity relationships of flavonoids and phenolic acids. Free Radical and Biology Medicine 20(7):933-56.

Rockenbach II, Rodrigues E, Cataneo C, Gonzaga LC, Lima A, Mancini-Filho J, Fett R (2008) Ácidos fenólicos e atividade antioxidante em fruto de Physalis peruviana L. Alimentos e Nutrição 19(3):271-276.

Rufino MSM, Alves RE, Brito ES, Morais SM, Sampaio CG, Pérez-Jiménez J, Saura-Calixto FD (2006) Metodologia Científica: Determinação da Atividade Antioxidante Total em Frutas pelo Método de Redução do Ferro (FRAP). Fortaleza: EMBRAPA Comunicado Técnico 125.

Rufino MSM, Alves RE, Brito ES, Morais SM, Sampaio CG, Pérez-Jiménez J, Saura-Calixto FD (2007) Metodologia Científica: Determinação da Atividade Antioxidante Total em Frutas pela Captura do Radical Livre DPPH. Fortaleza: EMBRAPA Comunicado Técnico 127.

Saad N, Delattre C, Uudaci M, Schmitter JM, Bressolier P (2013) An overview of the last advances in probiotic and prebiotic field. LWT - Food Science and Technology 50(1):1-16.
Sánchez-González I, Jiménez-Escrig A, Saura-Calixto $F$ (2005) In vitro antioxidant activity of brewed using different procedures (Italian, espresso and filter). Food Chemistry 90(1-2):133-139.

Siqueira AMO, Machado ECL, Stamford TLM (2013) Bebidas lácteas com soro de queijo e frutas. Ciência Rural 43(9):1693-1700.

Vasco C, Ruales J, Kamal-Eldin A (2008) Total phenolic compounds and antioxidant capacities of major fruits from Ecuador. Food Chemistry 111(4): 816-823

Vieira FGK (2010) Atividade antioxidante in vitro e in vivo de diferentes cultivares de maçã (Malus domestica Borkh) do estado de Santa Catarina. $170 \mathrm{f}$. Tese (Doutorado em Ciência dos Alimentos). Universidade Federal de Santa Catarina.

Vieira LM, Souza MSB, Mancini-Filho J, Lima A (2011) Fenólicos totais e capacidade antioxidante in vitro de polpas de frutos tropicais. Revista Brasileira de Fruticultura 33(3):888-897.

Wojdylo A, Oszmianski J, Laskowski P (2008) Polyphenolic compounds and antioxidant activity of new and old apple varieties. Journal of Agricultural Food Chemistry 56(15):6520-6530.

Yahia EM (2009) The contribution of fruit and vegetable consumption to human health. In: Benkeblia $\mathrm{N}$ (ed) Postharvest Technology for Horticultural Crops. Kerala: Research Signpost Publisher v. 2, pp.139-163.

Youmbi E. Zemboudem NM, Tonfack LB (2010) Changements morphologiques et biochimiques au cours du développement et de la maturation des fruits de Spondias cytherea Sonn. (Anacardiaceae). Fruit 65(5):285-292.

USDA. United States Department of Agriculture (2016). Dairy: world markets and trade. Disponível em: <http://usda.mannlib.cornell.edu/usda/fas/dairymarket/2010s/2016/dairy-market-07-22-2016.pdf> (Acessado em 15 jan 2017) 